Морозько А. П., Колесніченко О. В., Мельник В. І.

\title{
УДК: 582.097
}

\section{ПРОБЛЕМАТИКА СТРУКТУРНОЇ ІДЕНТИФІКАЦІЇ РОДИНИ}

\section{ARALIACEAE JUSS}

А. П. МОРОЗЬКО, аспірантка, https://orcid.org/0000-0002-0304-4450

E-mail: anasteziya.morozko@gmail.com

О. В. КОЛЕСНІЧЕНКО, доктор біологічних наук, професор

https://orcid.org/0000-0003-4767-6844

E-mail: okolesnichenko67@gmail.com

В. І. МЕЛЬНИК, кандидат сільськогосподарських наук, доцент

https://orcid.org/0000-0002-8782-1236

E-mail: vik4865@ukr.net

\section{Національний університет біоресурсів і природокористування Украӥни} https://doi.org/10.31548/dopovidi2020.01.014

Анотація. Родина Araliaceae Jиss. протягом усього періоду свого існування привертала увагу дослідників великою кількістю иікавих особливостей, щяо характеризують ї̈ з різних аспектів. Серед ії представників немає видів, які мають вагоме економічне значення, проте деякі характеризуються унікальними особливостями. Види Eleutherococcus sessiliflorus Rupr.et Maxim., Eleutherococcus senticosus (Rupr. \& Maxim.), Aralia elata (Miq.) Seem., Heder a helix L., Maxim, ma Kalopanax septemlobus (Thunb.) Koidz. є цінними пізніми медоносами. Мед зі зборів иих рослин має особливий смак, аромат та має лікувальні властивості, деякі з них також використовуються в кулінарії. Перші письмові згадки про ї̈ представників (Panax ginseng) в якості лікарських рослин датуються ще першим століттям до н.е. в стародавньому трактаті написаним Шен Нунгом - «Канон коренів $і$ трав Шень-нуна». Натяк на лікувальні властивості прихований навіть у родових назвах деяких рослин (Panax, Acanthopanax, Kalopanax, Heteropanax, Oreopanax, Tetrapanax, Oplopanax та ін.), адже латинське «рапах» походить від слова «панацея» (Pапасеа), тобто «ліки від усіх хвороб». У наш час спостерігається зменшення популяиії деяких представників родини, причинами якого насамперед $\epsilon$ антропогенні фактори до яких відносяться вирубка лісів і лісові пожежі, заготівля рідкісної дерени, неконтрольований збір підземних та наземних частин у якості иінної сировини для виготовлення лікарських препаратів за рахунок унікальних біохімічних властивостей, а також для використання 6 кулінарії. Відомо про випадок впливу зоогенних чинників на представників родини Araliaceae Juss. Tак у 1959 р. при вивченні рослинності заповідника «Кедрова долина» було помічено, що плямисті олені, у період наростання молодих пантів, викопують та поїдають корені E. sessiliflorus Rupr.et Maxim., а на території оленепарків рослини даного виду взагалі відсутні, адже були повністю знищені цими тваринами. Також на кількість популящії у бік зменшення безпосередньо впливають біологічні особливості иих видів. Нерегулярне визрівання насіння $і$ як наслідок - знижений потенціал до насіннєвого відтворення у Каlорапах septemlobus (Thunb.) Koidz. та слабка здатність до вегетативного 
Морозько А. П., Колесніченко О. В., Мельник В. I.

розмноження у поєднанні з вирубкою цих дерев, часто незаконною, з метою заготівлі цуіної деревини призводять до стрімкого скорочення чисельності.

Ключові слова: Araliaceae Juss., Hedea, Kalopanax, Aralia, Eleutherococcus, ботанічні сади Києва, лікарські рослини, синонім, прийнята ботанічна назва, колекційні насадження, далекосхідна флора, інтродукиія, систематичне положення, філогенетика

Актуальність. $\quad$ Структура родини Araliaceae Juss. для науковців $\epsilon$ надзвичайно цікавою та складною водночас. До ii складу входять види найрізноманітніших життєвих форм: дерева, багаторічні дерев'янисті ліани, а також багаторічні та однорічні трав'янисті рослини, проте більшість складають чагарники.

Представники досліджуваної родини зростають майже у всіх куточках земної кулі, за виключенням Антарктики. Переважно тропіки та субтропіки Східної та ПівденноСхідної Азії, Полінезії, Австралії, Південної та Північної Америки. В регіонах помірного клімату Північної півкулі Araliaceae Juss зустрічаються рідше, проте ще трапляються на територіï Канади (Fedorov, 1980, Rubtsov, et al. 1974, Takhtadzhian, 1970, Shchepotev, 1990). Найбільше різноманіття видів родини зосереджено в Східній і ПівденноСхідній Азії та на островах Тихого океану.

Крайні північні координати представників Araliaceae знаходяться на території Аляски (6950' північної широти та $162^{\circ} 77^{\prime}$ західної довготи) у вигляді викопних решток роду Scheffleraephyllum Г. Г. Філіппова 1988 p. (Shchepotev, 1990).
Великий об'єм та різноманіття видової структури родини призвели до того, що більш як 200 років вчені не мали одноголосної думки щодо приналежності деяких видів та родів саме до родини Araliaceae Juss.

Впродовж багатьох десятиліть простежувалась систематична близькість Araliaceae та Umbelliferae протягом всієї історії їх вивчення. Висока морфологічна схожість між цими двома родинами була помічена ще авторами штучних систем доліннеєвської епохи і знайшла своє відображення у більшості системпослідовників, що виникали після.

Родина вперше була описана А. Л. де Жюссье у 1789. Завдяки праці вченого Umbelliferae maAzaïaceae Juss. почали розрізняти в якості окремих, самостійних родин (Jussieu, 1789). Проте, таке положення завжди викликало питання та суперечки навколо себе, а деякі класики виступали за об'єднання у одну родину. Бентамом та Гукером була розроблена перша система родини (Bentham, Hooker, 1867).

У часи динамічного розвитку науки i техніки наш світ стрімко змінюється i на місце звичним підходам та методам досліджень біологічних систем, що були 
Морозько А. П., Колесніченко О. В., Мельник В. І. актуальними ще на початку минулого століття, приходять сучасні, в основу яких покладено останні розробки та технології. В свою чергу це призводить до спростування чи оновлення певної інформації, яка роками могла залишатися істинною та незмінною, а наразі вже $\epsilon$ неактуальною.

Систематика-необхідна основа будь-якої галузі ботаніки, адже вона характеризує взаємозв'язки між різноманітними рослинами, допомагає в упорядкуванні та класифікації існуючих i вимерлих представників рослинного світу і не менш важливо дає їм офіційні назви, що дозволяють фахівцям різних країн обмінюватися науковою інформацією (Takhtadzhian, 1987).

Проте положення деяких таксонів безпосередньо всередині родини і до теперішнього часу залишається нестабільним. Все частіше з'являються нові факти, що підтверджують чи спростовують інформацію щодо родинних зв'язків у Araliaceae Juss. Нині сучасна систематика грунтується не лише на морфологічному описі рослин, значну роль відіграє молекулярна філогенетика (Nechytailo, 1997, Wen, Zimmer, 1996). Розвиток саме цієї науки дає змогу науковцям виявити істинні далекі чи зовсім невідомі досі родинні зв'язки та якомога точніше систематизувати таксони між собою.

Так, завдяки розвитку досліджень в області молекулярної філогенетики

протягом останніх 20 років, науковці отримали нові методи для визначення родинних зв'язків між таксонами. Їх застосування, зі свого боку, спонукало до перегляду уявлень про філогенез деяких груп рослин, а також їх систематики.

Аналіз останніх досліджень та публікацій. Родина Araliaceae Juss. вже досить тривалий час докладно вивчається науковцями на предмет біохіміі та молекулярної філогенетики. Результати досліджень у цьому напрямку призводять до певних змін як у внутрішній структурі родини, так i поза піi межами. Відповідно до таксономічних досліджень 1996 року Дж. Вень і Е. А. Циммер, родина Araliaceae Juss. об'єднує дві великі монофілетичні групи: Aralia-Panax, яка складається 3 двох споріднених родів Aralia L. i Panax L. та групу азіатських пальмат (Wen, Zimmer, 1996), яка представлена родами Eleutherococcus Maxim., Dendropanax Decne. \& Planch i Schefflera J. R. Forst. \& G. Forst.

Подальший

аналіз даних

внутрішніх філогенетичний послідовностей транскрибованих спайсерів (ITC - Internal transcribed spacer) 70 видів 340 родів, що проводили Дж. Вень та ін. у 2001 р, також підтверджують поділ родини на дві великі групи: "Aralia-PolysciasPseudopanax" та "EleutherococcusDendropanax-Schefflera". Саме ці дослідження продемонстрували високу цінність ITC як маркера 
Морозько А. П., Колесніченко О. В., Мельник В. І. філогенетичних зв'язків у родині та дали поштовх до нових відкриттів пов'язаних 3 історією, темпами еволюціï та біогеографії представників Araliaceae на земній кулі.

Згодом, у спільних дослідженнях Г. Плункета та Дж. Вень у 2004 р., використано набір даних 3 двох молекулярних маркерів, ITS та інтрону спейсера знайденого в області trnL -trnF геному хлоропласта. Об'єм даних був більшим на 30\% ніж у попередньому (2001 р.) та становив 107 таксонів, які представляли 37 із 41 родів визнаних у той час у ядрі Araliaceae (Plunkett, Wen, Lowry, 2004). Але не зважаючи на те, що 66 одиниць для обох досліджень були спільними, виявлено деякі розбіжності у результатах окремо по кожному.

У ході об'єднання даних 3 цих двох маркерів встановлено, що існує три основні лінї Araliaceae. Найбільший 3 них клад "Азіатських пальмат" ("EleutherococcusDendropanax-Schefflera" у Вень та ін. 2001 р.), який у свою чергу включає 6 підгруп: Eleutherococcus (з родами Eleutherococcus, Kalopanax, Macropanax, Metapanax), Brassaiopsis (Brassaiopsis, Grushvitzkya, Trevesia, Hederá), Oreopanax (Oreopanax, Sinopanax), Gambela, (Gambeta Evodiopanax), Fatsia \{Dendropanax, Fatsia, Oplopanax) та підгрупа азіатських видів роду ScheUera (Tetr apanax, Heteropanax, MerrilHopanax та декілька видів 3 роду Schefflera) (Plunkett, Wen, Lowry, 2004).

Наступний за розміром "Polyscias-Pseudopanax", до складу якого входять 3 підгрупи: Polyscias (Polyscias, Reynoldsia, Tetrapiasandra, Munroidendron, Arthrophyllum, Gastonia, Cuphocarpus), тихоокеанська підгрупа видів Schefflera (Schefflera, Plerandra, Meryta) та Pseudopanax (Plunkett, Wen, Lowry, 2004).

Останній серед основних клад "Aralia " до якого входять роди Aralia (включно 3 Pentapanax), Panax i Sciadodendron. Решта ліній значно менші та зазвичай об'єднують лише 12 родини.

Результати

досліджень проведених Г. Плункетом та Дж. Вень у 2004 р. також свідчать про те, що 3 основні лінії родини, як правило, відповідають центрам біорізноманіття. Групи Азійских пальмат i Aralia зустрічається у Південно-Східній та Східній Азії, Polyscias-Pseudopanax зосереджені переважно у басейнах Індійського та Тихого океанів.

Порівняння результатів молекулярних досліджень із традиційними системами класифікації, заснованих переважно на морфологічних особливостях, майже повністю не виявляє відповідності та свідчить про те, що вони неповноцінно відображають філогенетичні зв'язки, оскільки такі особливості часто бувають 
Морозько А. П., Колесніченко О. В., Мельник В. І. гомопластичними, а отже $є$ недоцільними на деяких структурних рівнях родини (Plunkett, Wen, Lowry, 2004).

Завдяки цим дослідженням 3 молекулярної філогенетики, були внесені певні зміни у структуру родини. Так, Myodocarpus та Delarbrea традиційно розглядалися Araliaceae Juss., проте у системі Плункета та ін. (2004 р.) вони виділені в окрему родину Myodocarpaceae Doweld. Відомо, що ці два роди істотно відрізняються за деякими морфологічними ознаками (характером будови деревини), але не тільки від аралієвих, а і від Apiaceae i Pittosporaceae. Також у цій системі два роди Apiopetalum i Mackiniava виведені зі складу Araliaceae Juss. i віднесені у нову підродину Mackinlayoideae (Apiaceae), що також було встановлено на основі даних 3 молекулярної філогенетики (Plunkett, Wen, Lowry, 2004).

У 2011 році Шарма Шива і Пандіт Махарадж, отримали результати морфометричного аналізу видового комплексу Panax bipinnatifidus Seem. (Гімалаї, Індія), що свідчать про те, що Panax bipinnatifidus i P. sikkimensis $\epsilon$ частиною одного і того ж видового комплексу (Shiva, Maharaj, 2011).

Результати філогенетичного аналізу хлоропластів, що проводили корейські вчені Чанг-Куг Кім та ЮнКаб Кім свідчить, що $A$. cordata Thunb. тісно пов'язана 3 родом Panax L., (12. Філогенетичні дослідження
Планкета Г. М., Ловрі П. П. Гостеля M. Р. та ін. показали, що найбільший рід у Araliaceae Juss. - Schefflera, є надзвичайно поліфілетичним та представляє п'ять окремих клад у родині, i що один 3 них, котрий включає види 3 континентальної Африки, Мадагаскару, Коморських i Сейшельських островів, містить два морфологічно різних субклади (Lowry, Porter, et al. 2017).

У спробі встановити монофілетичні роди серед елементів, які налічував в рід Schefflera протягом останніх років, було відновлено роди Neocussonia (Harms) Hutch. (16 видів) i Astropanax Seem. (15 видів) для того, щоб охопити членів двох "афромалагасійських" субкладів (Lowry, Porter, et al. 2017).

У своїх дослідженнях Ендрю Перкінс щоб відновити філогенетичні зв'язки між однорічними видами Hydrocotyle L. 3 Південно-Західної Австраліі, використовував послідовності 3-х маркерів ДНК (Perkins, 2019).

На теперішній час систематика, структурна еволюція а також біогеографія представників родини Araliaceae головним чином залежить від темпів розвитку молекулярної філогенетики та всіх досліджень на їі основі.

Мета досліджень. На основі досліджень та сучасних даних провести аналіз структури i таксономічного складу колекцій родини Araliaceae Juss. у ботанічних 
Морозько А. П., Колесніченко О. В., Мельник В. І. садах міста Києва (ботанічний сад ім. акад. О. В. Фоміна Київського національного університету ім. Т. Г. Шевченка, Національний ботанічний сад ім. М. М. Гришка НАН України та ботанічний сад НУБіП України).

\section{Матеріали і методи}

дослідження. Під час проведення досліджень нами було опрацьовано матеріали деяких авторитетних міжнародних організацій серед них таксономічна класифікація квіткових рослин - Angiosperm Phylogeny Group IV (2016) [28], The Plant List об'єднана система таксономічної інформації королівського ботанічного саду «Кью» та ботанічного саду Miccypi [29], World Flora Online (WFO) - веб -компонування відомих видів рослин у світі 3 відкритим доступом (спільний міжнародний проект серед членів Глобального партнерства 3 охорони рослин (GPPC), який спирається на існуючі знання та опубліковані результати, контрольні списки та перегляди) [33], Integrated Taxonomic Information System (ITIS) - об'єднана система таксономічної інформації [9], база даних World Checklist of Selected Plant Families (WCSP) королівських ботанічних садів Кью [51]. Проаналізовано попередні дослідження та деякі літературні джерела написані у період XIX та XX століть. При написанні статті ми керувалися декількома методами наукових досліджень: статистичним, порівняльним, хронологічним та інформаційним.

Результати дослідження та їх обговорення. За різними даними кількість таксонів, що входила до складу родини Araliaceae завжди змінювалися та коливалися в межах від 47 до 80 родів та від 900 до 1350 видів (Kharkevych, 1987, Plunkett, Wen, Lowry, 2004). Однак кожні нові результати досліджень вносили певні зміни у структуру філогенетичного дерева родини.

Отже, проаналізовані нами джерела свідчать про те, що нині ця кількість становить 39 родів та 1443 види квіткових рослин (Nuralyev, M.S., Sokolov, D.D., Oskolskyi. A.A. (2017), The Angiosperm Phylogeny Group (2016), World Checklist of Selected Plant Families. Araliaceae), включаючи вимерлий рід Paleopanax 3 єдиним представником Paleopanax oregonensis, що був виявлений у середніх еоценових відкладах на півночі Орегону (Manchester, 1994).

На нашу думку, систематичне положення родини Araliaceae Juss. найточніше представлено в таксономічній класифікації квіткових рослин APG IV [28]: Domian Eukaryota Kindom Plantae Subkindom Viridaeplantae Phulum Streptophyta Subphulum Streptophytina (Embriophyta, Tracheophyta, Euphyllophyta, Spermatophyta) Infraclass Magnoliophyta Class Eudicots (Core eudicots, 
Морозько А. П., Колесніченко О. В., Мельник В. І. Superasterids) Subclass Asterids (Campanulids) Order Apiales Family Araliaceae Juss.

у багатьох літературних джерелах для деяких видів родини Araliaceae Juss., окрім ботанічних, часто використовуються застарілі синоніми та народні назви, що у певній мірі ускладнює процес дослідження. На Далекому Сході «чортове» або «шип-дерево», «чортовник», «шипук», «далекосхідна пальма», «японське ангелікове дерево» називають Aralia elata (Miq.) Seem. (Putyrskyi, Prokhorov, 2000), «Геркулесовий клуб», «колюча бузина», «колючий ясен», «чортова тростина» ідентифікуються також як Aralia spinosa L. (Keeler, Harriet, 1900).

Плющ звичайний - H. hélix L. (від грецької. Hedea - шнур + helliso витися, плестися) на західній частині України був відомий як «брочетан», «беречан», «берещан», «берещань», «боріштан», «блющ», «бриця», «повійка», «повійкан», «глисняк» (Zuzuk, Kutsyk, Zuzuk, 2003). У своїх віршах Б. I. Антонич описував рослину «прочитай» (Antonych, 1931). Kalopanax septemlobus (Thunb.) Koidz. також має декілька назв: «білий горіх» за особливості своєї деревини, «диморфант», «колюче касторове дерево» (Sangtae, Suniu 2015, Zhuravlev, Koliada, 1996). Такі назви як: «дикий перець», «акантопанакс тернистий», «чортів кущ», «вільноягідник колючий» відповідають ботанічній назві Eleutherococcus senticosus (Rupr. \& Maxim.) Maxim., a y деякій англомовний літературі про лікарські рослини зустрічається, як «сибірський женьшень» (Sibirian Ginseng) (Chevallier, A. 1996, Blynova K.F., Yakovlev H.P. 1990). Eleutherococcus sessilißorus Rupr.et Maxim, у Росії зустрічається під назвою «стосил» та «целебник» (Zhuravlev, Koliada, 1996).

Поряд 3 народними назвами вживаються також синоніми котрі в даний момент можуть бути неактуальними або ті, що вже $\epsilon$ спростованими, недійсними, неприйнятими чи навіть незаконними (Putyrskyi, Prokhorov, 2000, Worl Flora Online, The plant list). Синонімічний ряд Aralia elata за об'єднаною таксономічною системою The Plant List має 27 синонімів, де лише 7 мають високий рівень довіри, в свою чергу один $є$ незаконним, а другий недійсним. Також до цього ряду входять 3 інфравидові таксони, що мають власні синоніми, один серед них є лише варіантом написання (The plant list).

У деяких радянських виданнях часто зустрічається ботанічна назва Aralia mandshurica Rupr. \&Maxim., що згідно APG IV та The Plant List $\epsilon$ синонімом інфравидового таксона виду Aralia elata (Miq.). - Aralia elata var. mandshurica (Rupr. \& Maxim.) J.Wen. (The Angiosperm Phylogeny Group (2016), The plant list). Іншi 
Морозько А. П., Колесніченко О. В., Мельник В. І. джерела трактують, що ці два види дуже близькі між собою і відрізняються лише незначною шириною листочків та більш рихлим суцвіттям, також ці ознаки не $є$ суттєвими та не завжди строго витримані тому часто їх хибно приймають за один вид. Відповідно до об'єднаної системи таксономічної інформації королівського ботанічного саду «Кью» та ботанічного саду Miccypi Aralia elata (Miq.) налічує близько 27 синонімів, 5 з них \{Aralia canescens Siebold \& Zuce, Aralia emeiensis Z.Y.Zhu, Aralia hupehensis G.Hoo, Aralia subeapitata G.Hoo, Dimorphanthus elatus Miq.) мають високий рівень довіри, ще 2 Aralia japónica та Aralia elata var. subinermis Ohwi є незаконними, a. Aralia granáis Miq. - недійсним.

Eleutherococcus - це ще один рід 3 родини Araliaceae 3 кризою ідентичності. Спочатку він був визнаний як підрід Panax (5, пізніше у 1861 році Г. Вітте підняв його до родового рангу. Проте у своїй системі класифікації, що опублікували задовго до того, як було прийнято міжнародні правила ботанічної номенклатури, Дж. Бентам i Дж. Гукер виокремлюють і Acanthopanax i Eleutherococcus (Bentham, Hooker, 1867). У період з 1894 по 1978 рр. завдяки Т. Хармсу ці два роди помилково об'єднують в один під спільною родовою назвою Acanthopanax, яка ще довго використовувалась багатьма вченими
(Greuter, 1994). Тим не менш, ця назва не $є$ легітимною і не має пріорітету, адже найдавнішою та найпершою вважається Eleutherococcus Maxim., рід описаний у 1859 р. К. I. Максимовичем (Chevallier, 1996). Нарешті, 31978 р. по наші дні офіційною та законно прийнятою назвою є Eleutherococcus Maxim., а останні таксони 3 колишнього Acanthopanax китайські вчені Пінг i Шен перенесли лише у 1993р. Таким чином, згідно з матеріалами сучасних авторитетних організацій, усі види які раніше входили до Acanthopanax нині належать до Eleutherococcus Maxim. (The plant list, World Flora Online, Integrated Taxonomic Information System IT IS, World Checklist of Selected Plant Families).

У деяких джерелах радянських та пострадянських часів автори хибно виділяли два окремих роди Eleutherococcus Maxim, та Acanthopanax (Takhtadzhian, 1970, Shchepotev, 1990, Bohdanov, 1974, Zaiachuk, 2014). А в деякій літературі далекосхідної флори Eleutherococcus senticosus (Rupr. \& Maxim.) Maxim, не вирізняли окремим родом, а розглядали у складі роду Acanthopanax (Voroshylov, 1982, Voroshylov, 1966, Ohwi, 1965), але у літературних джерелах про флору Кореї та Китаю він ідентифікується як складова роду Eleutherococcus Maxim.

На сьогоднішній день колекційні насадження родини Araliaceae Juss. у Києві представлені на ділянках 3 
Морозько А. П., Колесніченко О. В., Мельник В. І. ботанічних садів. До колекції видів, що зростають на території ботанічного саду Національного університету біоресурсів і природокористування України належать 4 таксони, серед них 2 види роду Eleutherococcus Maxim. (E. senticosus (Rupr. \& Maxim.) Maxim, та E. sessiliflorus Rupr. \& Maxim.) та 23 роду Aralia L. (A. elata (Miq.) і $A$. cordata Thunb.), $H$. helix L. та $K$. septemlobus (Thunb.) Koidz. - єдині представники з Hedera L. Walopanax Miq., більша кількість 3 яких тут з'явилися наприкінці 70 -х років $\mathrm{XX}$ століття.

У колекції незахищеного грунту ботанічного саду ім. акад. О. Фоміна Київського національного університету ім. Т. Шевченка налічується 3 таксони, що представлені 9 видами рослин родини Araliaceae Juss., серед них рід Eleutherococcus Maxim, є найбільшим і налічує 6 видів (E. senticosus (Rupr. \& Maxim.) Maxim., E. sessiliflorus Rupr. \& Maxim., E. trifoliatus (L.) S.Y.Hu, E. wardii (W.W.Sm.) S.Y.Hu raf. sieboldianus (Makino) Koidz.). Vom Aralia L. та Hedera L. мають у своєму складі по два представника (A. elata (Miq.) та $A$. cordata Thunb., H. helix L. i H. colchica (K.Koch) K.Koch). Ці рослини були інтродуковані в ботанічному розсаднику дослідної станції лікарських рослин у 60-х роках XX століття та зростають по теперішній час.

\begin{tabular}{|l|c|c|c|}
\hline \multicolumn{1}{|c|}{ Прийнята ботанічна назва } & $\begin{array}{c}\text { Ботанічний сад їм. } \\
\text { акад. 0. Фоміна КНУ } \\
\text { ім. Т. Шевченка }\end{array}$ & $\begin{array}{c}\text { Ботанічний } \\
\text { сад НУБІП } \\
\text { України }\end{array}$ & $\begin{array}{c}\text { НБС ім. М.М. } \\
\text { Гришка НАН } \\
\text { України }\end{array}$ \\
\hline A. cordata Thunb. & + & + & + \\
\hline A. data (Miq.) & + & + & + \\
\hline E. lasiogyne Harms. & - & & + \\
\hline E. senticosas (Rupr. \& Maxim.) Maxim. & + & + & + \\
\hline E. sessiliflorus Rupr. \& Maxim. & + & - & - \\
\hline E. sieboldianus (Makino) Koidz. & + & - & - \\
\hline E. trifoliatus (L.) S.Y.Hu & + & - & - \\
\hline E. wardii (W.W.Sm.) S.Y.Hu & + & - & - \\
\hline H. colchica (K.Koch) K.Koch) & + & + & + \\
\hline H. helix L. & + & + & - \\
\hline K. septemlobus (Thunb.) Koidz. & - & & \\
\hline
\end{tabular}

Зазначимо, що до 5 з 6 видів роду Eleutherococcus Maxim, (окрім E. senticosus (Rupr. \& Maxim.) Maxim.) досі вживається стара родова назва Acanthopanax, незалежно від їх місцезростання, а A. elata (Miq.) по сьогоднішній день відома як Aralia mandshurica Rupr. \&Maxim.

Висновки і перспективи. Історії вивчення Araliaceae завжди була і до тепер залишається динамічною. У спробах дослідити iї систематичну структуру та філогенетичні зв'язки, 
Морозько А. П., Колесніченко О. В., Мельник В. І. біохімічний потенціал, біогеографію й структурну еволюцію брала участь велика кількість вчених не менш як чотирьох поколінь.

Проблема вчасного оновлення наукової інформації у світі сучасних технологій дотепер залишається актуальною. Серед великої кількості інформації, яка нині існує переважно у вільному доступі для зацікавленої людини є і та, що вже неактуальна, проте надалі невірно сприймається та

\section{Список використаних джерел}

1. Antonych, B.Y. (1931). Greetings to life. Lviv: Dazhboh, 31. (in Ukrainian).

2. Blynova K.F., Yakovlev H.P. (1990). Botanical-Pharmacological Dictionary: Reference Manual.Moscow: Vysshaya shkola, 262. (in Russian). Bentham, G., Hooker, J. D. (1867). Gener a plantarum. Londini, 1, 454.

3. Bohdanov, P.L. (1974). Dendrology. Textbook for universities. Moscow: Lesnaia Promyshlennost, 114-116. (in Russian).

4. Chevallier, A. (1996). The encyclopedia of medicinal plants. London: Dorling Kinder Sley, 336.

5. Decaisne, J., Planchon, J.E. (1854). Sketch of a monograph of Araliaceae. Revue Horticole. Marseille, 4 (3), 104-109. (in French).

6. Fedorov, A.A. (1980). Plant Life in 6 volumes. Moscow: Prosviashchenye, 450. (in Russian).

7. Global Biodiversity Information Facility. Araliaceae. Available at: https://www.gbif.org/species/8800

8. Greuter, W., Barrie, F.R., Burdet, H.M., Chaloner, W.G., Demoulin, V., Hawksworth, D.L., Jorgensen, P.M., Nicolson, D.H., Silva, P.C., Trehane, P. and McNeill, J. (1994). International Code of Botanical Nomenclature (Tokyo Code). Regnum vegetabile, 131,389.

9. Integrated Taxonomic Information System ITIS. Available at: https://www.itis.gOv/servlet/SingleRpt/SingleR pt\#null дублюється на різних носіях створюючи певний дискомфорт $\mathrm{y}$ пошуках. Разом з такими джерелами інформації поряд зустрічається також деяка наукова література 3 XIX століття.

Систематику та філогенію родини наразі продовжують вивчати, а зважаючи на стрімкий прогрес та розвиток науки, техніки і технологій слід очікувати нових відкриттів, змін та перетворень.

10. Jussieu A. L. (1789). Genera plantarum secundum ordines naturales disposita. Paris, 489.

11. Keeler, Harriet L. (1900). Our Native Trees and How to Identify Them. New York: Charles Scribner's Sons, 165-168.

12. Kharkevych, S.S. (1987) Vascular plants ofthe Soviet Far Eastern. Lenynhrad: Nauka, 2. 195-203. (in Russian).

13. Kim, Chang-Kug. \& Kim, YongKab. (2019). The complete chloroplast genome of Aralia cordata (Apiales: Araliaceae). Mitochondrial DNA Part B-resourses, 4(1), 211212.

https://doi.org/10.1080/23802359.2018.154614 $\underline{0}$

14. Lowry, Porter P., Plunkett, Gregory M ., Gostel, Morgan R., Frodin, David G. (2017). A synopsis of the Afro-Malagasy species previously included in Schefflera (Araliaceae): resurrection of the genera Astropanax and Neocussonia. Candollea, 72 (2), 256-282. https://doi.org/10.15553/c2017v722a4

15. Manchester, S.R. (1994). Fruits and Seeds of the Middle Eocene Nut Beds Flora, Clarno Formation, Oregon. Palaeontographica Americana, 58, 30-31.

16. Nechytailo, V.A.

(1997).

Systematics of higher plants. Angiosperms. Kyiv: Naukova Dumka, 272. (in Ukrainian).

17. Nuralyev, M.S., Sokolov, D.D., Oskolskyi. A.A. (2017). The evolutionary morphology ofthe flower Araliaceae (as exemplified by Asian representatives ofthe genus Schefflera). Moscow: MAKS Press, 4-5. (in Russian). 
Морозько А. П., Колесніченко О. В., Мельник В. І.

18. Ohwi, J. (1965). Flora of Japan. Washington, D. C: Smithsonian Institution, 664.

19. Perkins, A.J. (2019). Molecular phylogenetics and species delimitation in annual species of Hydrocotyle (Araliaceae) from South Western Australia. Molecular phylogenetics and evolution, 134, 129-141. https://doi.org/10.1016 / j.ympev.2019.02.011

20. Plunkett, G.M., Wen J., Lowry II P.P. (2004). Infrafamilial classifications and characters in Araliaceae: insights from the phylogenetic analysis of nuclear (ITS) and plastid (trnLtrnF) sequence data. Plant Systematics and Evolution, 245, 1-39.

21. Putyrskyi, Y.N., Prokhorov, V.N. (2000). Universal Encyclopedia of Medicinal Plants. Moscow: Makhaon, 56-58. (in Russian).

22. Rubtsov, L.I., Hordyenko Y.Y., Kaplunenko, M.F. (1974). Trees and shrubs. Directory. Kyiv: Naukova Dumka, 590. (in Russian).

23. Sangtae. L., Chang, K.S. (2015). English names for Korean native plants. Pocheon: Korea National Arboretum, 760.

24. Serebriakov, Y.H. (1955). The main directions of the evolution of life forms in angiosperms. Bull. MSN. Dep. biol., 60 (3), 71 (in Russian).

25. Sharma, Shiva \& Pandit, Maharaj. (2011). A morphometric analysis and taxonomic study of Panax bipinnatifidus Seem. (Araliaceae) species complex from Sikkim Himalaya, India. Plant Systematics and Evolution, 297, 87- 98. https://doi.Org/1 0.1007/s00606-011-0501-8

26. Shchepotev, F.L. (1990). Dendrology. Tutorial. Kyiv: Vyshcha Shkola, 287. (in Russian), (in Russian).

27. Takhtadzhian, A. L. (1987). Magnoliophyte System. Leningrad: Nauka, 439. (in Russian).
28. Takhtadzhian, A.L. (1970). The origin and settlement of flowering plants. Leningrad: Nauka, 147.

29. The Angiosperm Phylogeny Group (2016). An update of the Angiosperm Phylogeny Group classification for the orders and families of flowering plants: APG IV. Botanical Journal of the Linnean Society, 181 (1), 1-20. https://doi.org/10.1111/boj.12385

30. The plant list. Angiosperms. Araliaceae. Available at: http://www.theplantlist.0rg/l.

1/browse/A/Araliaceae/

31. Voroshylov, V.N. (1966). Flora of the Soviet Far East. Moscow: Nauka. 478. (in Russian).

32. Voroshylov, V.N. (1982). Key to plants of the Soviet Far East. Moscow: Nauka, 414. (in Russian).

33. Wen, J., Zimmer E.A. (1996). Phylogeny and biogeography of Panax L. (the ginseng genus, Araliaceae): inferences from ITS sequences of nuclear ribosomal DNA. Molecular Phylogenetics and Evolution, 6 (2), 167-177.

34. Worl Flora Online. Araliaceae. Available at: http://www.worldfloraonline.org/taxon/wfo7000000043

35. World Checklist of Selected Plant Families. Araliaceae. Available at: http://wcsp.science.kew.org.

36. Zaiachuk, V.Y. (2014).

Dendrology. Lviv: SPOLOM, 676. (in Ukrainian).

37. Zhuravlev, Y.N, Koliada, A.S. (1996). Araliaceae: ginseng and others. Vladyvostok: Dalnauka, 280. (in Ukrainian).

38. Zuzuk, B.M., Kutsyk, R.V., Zuzuk, L.Y. (2003). Curly ivy Hedera helix L. Analytical review. Provyzor, 11. (in Russian).

\section{PROBLEMS OF STRUCTURAL IDENTIFICATION OF THE ARALIACEAE JUSS FAMILY A.P. Morozko, O. V. Kolesnichenko, V. I. Melnyk}

Abstract. Family Araliaceae Juss. throughout the period of its existence has attracted the attention of researchers with a large number of interesting features that characterize it from different aspects. Among its representatives there are no species that have significant economic significance, but some are characterized by unique features. See Eleutherococcus sessiliflorus Rupr.et Maxim., Eleutherococcus 
Морозько А. П., Колесніченко О. В., Мельник В. І.

senticosus (Rupr. \& Maxim.), Aralia elata (Miq.) Seem., Heder a helix L., Maxim, and Kalopanax septemlobus (Thunb.) Koidz. are valuable late honeysuckle. Honey from the collections of these plants has a special taste, aroma and medicinal properties, some of which are also used in cooking. The first written mention of its representatives (Rapah ginseng) as a medicinal plant dates back to the first century BC. in an ancient treatise written by Shen Nung - "Canon of the roots and herbs of Shen-nun." The hint of medicinal properties is hidden even in the generic names of some plants (Rapah, Acanthopanax, Kalopanax, Heteropanax, Oreopanax, Tetrapanax, Oplopanax, etc.), because the Latin "rapah" comes from the word "panacea" (Rapasea), ie medicine diseases ". Nowadays there is a decrease in the population of some members of the family, the causes of which are primarily anthropogenic factors which include deforestation and forest fires, harvesting of rare turf, uncontrolled collection of underground and terrestrial parts as valuable raw materials for drugs due to unique biochemical properties. also for culinary use. It is known about the influence of zoogenic factors on members of the family Araliaceae Juss. Thus, in 1959, when studying the vegetation of the reserve "Cedar Valley" it was noticed that spotted deer, during the growth of young antlers, dig up and eat the roots of E. sessiliflorus Rupr.et Maxim., And in reindeer parks plants of this species are absent, because were completely destroyed by these animals. Also, the number of populations in the direction of reduction is directly affected by the biological characteristics of these species. Irregular seed maturation and, as a consequence, reduced potential for seed reproduction in Kalopanax septemlobus (Thunb.) Koidz. and a weak ability to reproduce vegetatively in combination with the felling of these trees, often illegal, in order to harvest valuable timber, leading to a sharp decline in numbers.

Key words: Araliaceae Juss., Hedea, Kalopanax, Aralia, Eleutherococcus, botanical gardens of Kyiv, medicinal plants, synonym, accepted botanical name, collection plantations, Far Eastern flora, introduction, systematic position, phylogenetics 